\title{
AHP-ENHANCED SWOT MATRIX TEACHING STRATEGY
}

\section{ESTRATEGIA DE ENSEÑANZA DE LA MATRIZ FODA EXTENDIDA CON AHP}

\author{
Mario Chipoco Quevedo* \\ Universidad Peruana de Ciencias Aplicadas, Perú
}

\begin{abstract}
The SWOT matrix is the quintessential analysis tool for business purposes, and is taught both in undergraduate and postgraduate courses. However, it is widely understood that the selection of the critical success factors (CSFs) that are included for analysis in the matrix is a very subjective and unstructured process, leaving room for bias and arbitrariness. One way to give a better foundation and support to the analysis results is by utilizing Analytic Hierarchical Process (AHP) in order to weigh the importance of CSFs in the SWOT matrix and increase reliability of the output. This paper contains the design of a strategy to teach this topic in a marketing planning course, with the addition of a useful technique to overcome the limitations of the tool.
\end{abstract}

Keywords: SWOT matrix, analytic hierarchical process, teaching strategy.

\section{RESUMEN}

La matriz FODA es la herramienta de análisis por excelencia para fines de negocios, y se enseña en cursos de pregrado y postgrado. Sin embargo, se entiende que la elección de los factores críticos de éxito (FCEs) que se incluyen en la matriz para el análisis es un proceso muy subjetivo y no estructurado, que da cabida a sesgos y arbitrariedad. Una forma de dar una mejor base y respaldo a los resultados del análisis es mediante la utilización del Proceso Jerárquico Analítico (AHP) con el fin de ponderar la importancia de los FCEs en la matriz FODA y aumentar la fiabilidad de los resultados. Este documento contiene el diseño de una estrategia para enseñar este tema en un curso de planificación de marketing, con la adición de una técnica útil para superar las limitaciones de la herramienta.

Palabras clave: matriz FODA, proceso analítico jerárquico, estrategia de enseñanza. 


\section{INTRODUCTION}

SWOT analysis is a highly utilized tool to implement strategic management processes in organizations. As such, it is included in undergraduate and postgraduate business and marketing planning courses. Even though it is widely used in academia and corporate environments, its origin is not well documented, as noted by Panagiotou (2003), and apparently, this tool originated in several places and became mainstream in the 1960s. Despite its wide utilization, SWOT analysis has notorious shortcomings, such as vagueness or lack of detail in the description of critical success factors, and it frequently relies on an oversimplified process (Panagiotou, 2003).

In order to maintain the usefulness of this tool, it is necessary to follow a standard set of common sense rules and advanced techniques to achieve a proper level of analysis. Since managers and entrepreneurs usually get acquainted with this matrix during university professional studies, it is a good practice to provide complete guidelines to teach this subject based on a more complex business environment. This paper provides a design of such strategy for a marketing planning course.

\section{Revision of literature}

The basic guidelines to perform a SWOT analysis are contained in most textbooks dealing with business and marketing planning. David (2014) gave a full description of the basic methodology to perform the analysis, as part of the planning process stage where the organization's capabilities and resources to face threats and opportunities are assessed. David indicated that the analysis work requires good intuitive judgments to identify and determine proper weights and rankings of CSFs. He also described the nine-quadrant matrix and the four types of strategies that can be derived from the SWOT matrix:

Table 1

Strategies from SWOT analysis

\begin{tabular}{lcc}
\hline SWOT matrix & Strengths & Weaknesses \\
\hline Opportunities & Use strengths to seize opportunities & Overcome weaknesses to \\
& Seize opportunities \\
Threats & Use strengths to avoid threats & Overcome weaknesses to \\
\end{tabular}

Note: Adapted from Strategic management: a competitive advantage approach, concepts \& cases (p. 169), by F. R. David, 2014, New Jersey: Prentice Hall. Copyright 2014 by Pearson Education, Inc.

David also provided common sense advice on typical situations, some sort of recipes to be applied according to the external environment and the resources and capabilities of the organization. The election of strategies is the most important part of this process, and it is backed-up by strategic intuition (D’Alessio, 2008), because it demands not only a systematic method, but also creativity and business instincts from managers. SWOT analysis provides strategic alternatives, or choices of future strategies to be pursued, given the company's internal strengths and weaknesses, and its external opportunities and threats (Hill, Jones \& Schilling, 2014). In a large business, SWOT analysis is carried out ideally 
by a multi-disciplinary team in a workshop dedicated to the preparation of such analysis, with the objective of gaining sustainable competitive advantage (Friend \& Zehle, 2004). The process of identifying strategic issues that will affect an organization's environment at some future time is called internal environmental forecasting and it is a critical step in SWOT analysis (Rao, 2010).

Addressing the marketing plan design specifically, Sainz de Vicuña (2010) said that the strengths and weaknesses must be related to competitive advantages and disadvantages, because this approach is more useful for defining a marketing strategy than the utilization of strengths and weaknesses, due to the key role of customer perspectives and degree of rivalry with competitors. The SWOT analysis must be conducted for each relevant segment of the company's future, and it summarizes the marketing audit (McDonald, 2011). Managers must evaluate the issues within the matrix in terms of their magnitude and importance, and ideally, this evaluation should be based on customers' perception (Ferrell \& Hartline, 2011). These authors also indicate that even though it is not mandatory that the SWOT matrix be assessed quantitatively, they suggest the use of a scale to quantify how strongly the CSFs affect the firm (Ferrell \& Hartline, 2011). Kotler \& Keller (2015) wrote that the business units must analyze the macro- and micro-environment forces that affect their capacity to generate profit, and that a marketing opportunity is the buyers' every need or interest that the firm can satisfy profitably. They also provided a roster of key CSFs to be assessed and valued according to their magnitude and importance. Due to a changing external environment, it is mandatory to continuously track competition and other key elements of the market system, so as to determine what patterns are developing (Vass, 2005).

The limitations of the tool have been discussed and many improvements have been suggested by academic researchers. The open nature and unstructured method of SWOT offers little help to users, who are left without guidance on where to search for such variables, or what to do afterwards, in terms of how best to incorporate them in the strategy formulation (Panagiotou, 2005). Among other flaws, the following were mentioned by Coman \& Ronen (2009):

- No straightforward methodology is provided to identify strengths and weaknesses.

- Most SWOT analyses focus on an excessive number of the organization's strengths and weaknesses rather than on the main ones, which makes it difficult to utilize the findings to design the actions.

- There is no indication of causality among the strengths and weaknesses, nor are they ranked into any hierarchy.

- The SWOT analysis is typically a onetime event lacking procedures for acting upon and tracking the changes in strengths and weaknesses over the longer term.

A research on 20 UK manufacturing companies carried out by Hill \& Westbrook (1997) showed that the SWOT matrices contained long lists of CSFs (over 40 on average), general (often meaningless) descriptions, a failure to prioritize, no attempt to verify points, and no subsequent utilization of the outputs within the later stages of the strategy process.

Due to these limitations, different frameworks have been proposed to improve the results and its utilization within organizations. 
One logical approach is to provide a set of guidelines for the identification and selection of CSFs, as proposed by Panagiotou (2003), who offered the set of factors shown in Figure 1.
Under this framework, the CSFs are systematically identified to be ranked and crossanalyzed afterwards using a process similar to the basic SWOT method.

\begin{tabular}{|c|c|c|c|c|c|c|c|c|c|c|c|}
\hline & & $\begin{array}{l}\text { Technological } \\
\text { Advancements }\end{array}$ & $\begin{array}{c}\text { Economic } \\
\text { considerations }\end{array}$ & $\begin{array}{l}\text { Legaland } \\
\text { regulatory } \\
\text { requirements }\end{array}$ & $\begin{array}{l}\text { Ec ologicaland } \\
\text { environmental } \\
\text { issues }\end{array}$ & $\begin{array}{c}\text { Sociological } \\
\text { trends }\end{array}$ & Competition & $\begin{array}{l}\text { Organizational } \\
\text { culture }\end{array}$ & Portfolio analys is & $\begin{array}{c}\text { International } \\
\text { issues }\end{array}$ & \begin{tabular}{|c} 
Cost efficiencies \\
and cost \\
structures
\end{tabular} \\
\hline Internal & Strengths & & & & & & & & & & \\
\hline Environment & Weaknesses & & & & & & & & & & \\
\hline External & Opportunities & & & & & & & & & & \\
\hline Environment & Threats & & & & & & & & & & \\
\hline
\end{tabular}

Figure 1. First part of the analysis framework to identify CSFs. Adapted from "Bringing SWOT into focus", by G. Panagiotou, 2003, Business Strategy Review, 14(2), p 10. Copyright 2003 by Blackwell Publishing Limited.

An additional set of factors is shown in Figure 2.

\begin{tabular}{|c|c|c|c|c|c|c|c|c|c|c|c|c|}
\hline & & $\begin{array}{c}\text { Core } \\
\text { competences } \\
\text { and capabilities } \\
\end{array}$ & Buyers & Suppliers & $\begin{array}{l}\text { Electronics } \\
\text { commerce }\end{array}$ & Resource audit & Value chain & $\begin{array}{c}\text { Alliances, } \\
\text { partnerships, } \\
\text { networks } \\
\end{array}$ & $\begin{array}{l}\text { Total quality } \\
\text { management }\end{array}$ & $\begin{array}{c}\text { Industry key } \\
\text { success factors }\end{array}$ & Newentrants & $\begin{array}{l}\text { Substitute } \\
\text { products }\end{array}$ \\
\hline Internal & Strengths & & & & & & & & & & & \\
\hline Environment & Weaknesses & & & & & & & & & & & \\
\hline External & Opportunities & & & & & & & & & & & \\
\hline Environment & Threats & & & & & & & & & & & \\
\hline
\end{tabular}

Figure 2. Final part of the analysis framework to identify CSFs. Adapted from "Bringing SWOT into focus", by G. Panagiotou, 2003, Business Strategy Review, 14(2), p 10. Copyright 2003 by Blackwell Publishing Limited.

As mentioned before, basic SWOT methodology does not provide the means for an analytical determination of the importance of the factors or of assessing the decision alternatives with respect to them. To overcome this shortcoming, a quantitative AHP analysis can be utilized to determine priorities among SWOT factors systematically. This is obtained by performing pairwise comparisons between identified SWOT CSFs. After that, comparison matrices are analyzed by the eigenvalue method applied in AHP to calculate priorities and assign the relative importance of each SWOT factor (Görener, Toker \& Uluçay, 2012).

AHP is a multi-criteria decisionmaking technique that can help model the general decision operation by dividing a complex problem into a multilevel hierarchical structure of objective, criteria and alternatives. AHP performs pairwise comparisons to derive relative importance of the variable in each level of the hierarchy, and assesses the alternatives in the lowest level of the hierarchy to make the best decision among alternatives. AHP is effective especially when there is subjectivity and it is very suitable to solve problems where the decision criteria can be organized into subcriteria in a hierarchical way (Görener, Toker, \& Uluçay, 2012). The prioritization process is achieved by using the scale developed by Saaty (1980) and it is shown in Table 2 .

Then, the SWOT matrix can be modeled as a three level hierarchy: the goal to be 
Table 2

The fundamental scale developed by Saaty

Importance Explanations

1

Two criteria contribute equally to the objective

Experience and judgment slightly favor one over another

Criterion is strongly favored and its dominance is demonstrated in practice

Note: Reprinted from "Application of combined SWOT and AHP: a case study for a Manufacturing Firm", by A. Görener, K. Toker \& K. Uluçay, 2012, Procedia-Social and Behavioral Sciences, 58, p. 1527. Copyright 2012 by Elsevier Ltd. Selection.

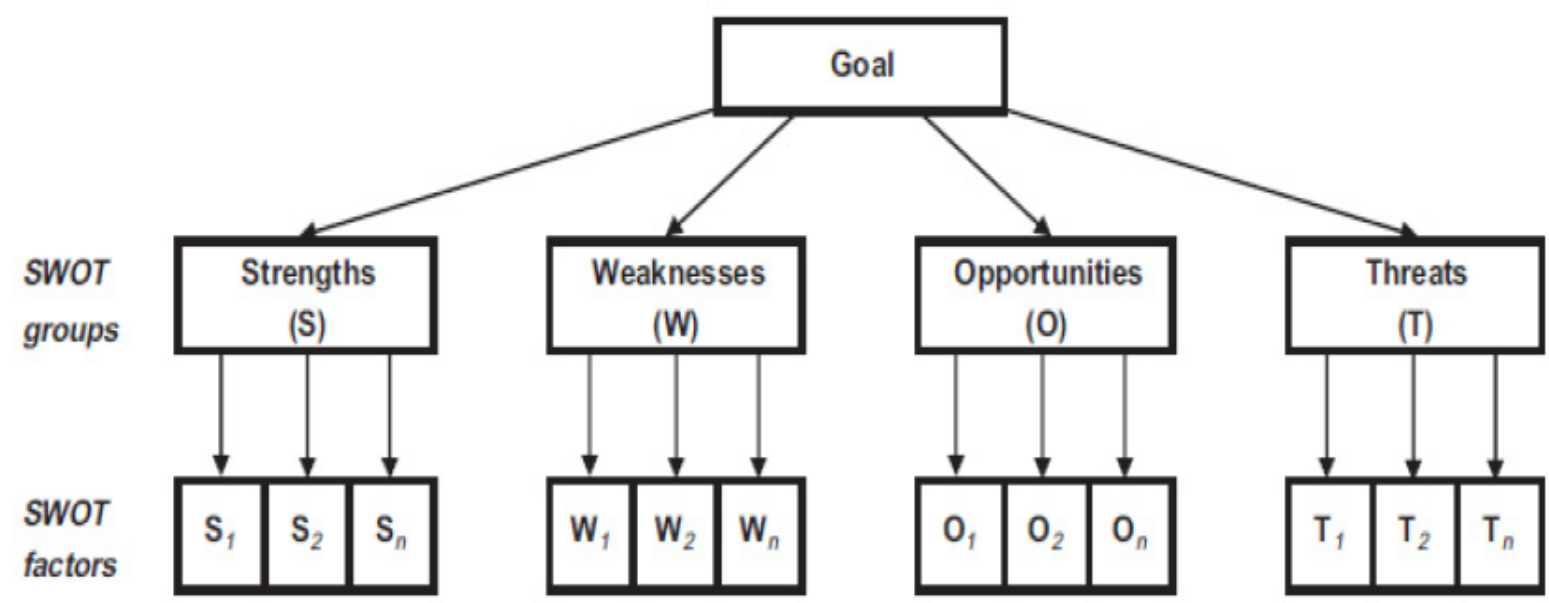

Figure 3. Hierarchical structure of the SWOT matrix. This figure illustrates the process for prioritizing CSFs. Reprinted from "Application of combined SWOT and AHP: a case study for a Manufacturing Firm", by A. Görener, K. Toker \& K. Uluçay, 2012, Procedia-Social and Behavioral Sciences, 58, p. 1529. Copyright 2012 by Elsevier Ltd. Selection. 
achieved with the decision, the group CSFs and the individual CSFs, as depicted in Figure 3.

The next step is to set up a matrix to carry out pairwise comparisons of the relative importance of the elements in the second level with respect to the overall goal of the first level, according to the fundamental scale of Table 3, so as to create a matrix as shown in Table 3.

Table 3

Structure of the comparison matrix

\begin{tabular}{|c|c|c|c|c|c|}
\hline SWOT Groups & S & W & 0 & $\mathrm{~T}$ & $\begin{array}{c}\text { Importance Degrees of } \\
\text { SWOT Groups }\end{array}$ \\
\hline Strengths (S) & 1 & $\mathrm{a}_{12}$ & $\mathrm{a}_{13}$ & $a_{14}$ & $\mathrm{I}_{\mathrm{s}}$ \\
\hline Weaknesses (W) & $1 / a_{12}$ & 1 & $1 / a_{23}$ & $\mathrm{a}_{24}$ & $I_{w}$ \\
\hline Opportunities (0) & $1 / a_{13}$ & $1 / a_{23}$ & 1 & $\mathrm{a}_{24}$ & $\mathrm{I}_{\mathrm{o}}$ \\
\hline Threats $(\mathrm{T})$ & $1 / a_{14}$ & $1 / a_{24}$ & $1 / a_{34}$ & 1 & $I_{t}$ \\
\hline
\end{tabular}

Where:

$a_{i j}$ : the assigned judgment value according to the scale of Table 3

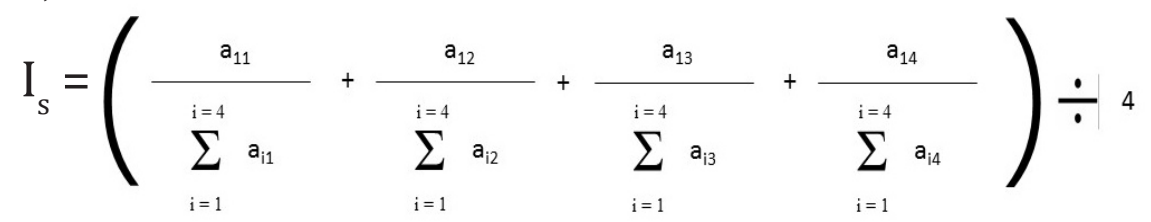

The importance degrees or priorities of the other groups $\left(I_{w}, I_{o^{\prime}}, I_{t}\right)$ are calculated with a similar procedure, deriving a ratio scale for the level. After that, additional comparison matrices are generated with the CSFs of the third level, with respect to the corresponding parents in the second. The next step deals with the composition of the derived ratio scales. Priorities are synthesized by multiplying priorities from the third level by the priority of their corresponding criterion in the second level. Finally, this process contains an intrinsic measure of inconsistency for each matrix and for the whole hierarchy. Knowledge of inconsistency allows to determine those judgments which need reassessment (Saaty, 1980).

Having considered the improvement in the planning procedure and the results by means of applying additional frameworks to the usual SWOT method, a better way to explain this analysis tool is desirable, in order to raise the quality of the knowledge to be shared with students. Therefore, some enhancements can be added to the usual course content to achieve this goal. 


\section{Teaching strategy guide}

A guide was designed to provide orientation to teach SWOT analysis for undergraduate and postgraduate marketing courses.Companion PowerPointand Excelfiles are provided as complementary documents to this paper. The design process was based on the reviewed literature, which provided the background to develop basic concepts and an example where the theory is applied by utilizing a step-by-step method, based on the calculations displayed on the slides and on the spreadsheet as well. The conventional topics of SWOT matrix are revisited briefly, in order to set up a context for the analysis tool to be explained. The focus of the learning session would be to emphasize the decomposition of the problem under study on different levels of factors, so a systematic analysis can be applied to obtain relative weights, to facilitate resource assignment at further stages of the planning process. This guide is shown in the following paragraphs:

\section{Subject: SWOT analysis}

Mode: Live, e-learning, blended

Audience: Undergraduate and postgraduate students of Marketing Plan courses. Typically, undergraduate students of the last year of the career take this course, as it is considered an advanced subject, so it is mandatory to have knowledge of basic concepts such as marketing mix, branding, and similar matters. This is the reason why undergraduate students can be considered a suitable audience for the material covered in this paper. Similarly, postgraduate students take a Marketing Plan course as part of the program for executive education or MBA curriculum. A Marketing Plan course deals mainly with the concepts of macro- and microenvironment analysis, a broad range of tools to assess the relevant data, determination of objectives, and design of strategies.

\section{Estimated time: Two hours}

Location: Classroom with presence of teacher; remote via Internet

Focus: Broaden the knowledge of students with improved tools

Justification: SWOT analysis is widely used but their limitations are well known; a need to improve the procedure and results is highly desirable

Purpose: Raise the level of content for marketing courses and provide additional value to students Content: A document with the suggested transcript of the class, slides with images and bullets to describe main concepts, and an example spreadsheet with calculations

Required previous knowledge: Basic arithmetic and spreadsheet skills

Suggested class transcript: see Appendix A

\section{Classroom}

In live classes with undergraduate and postgraduate students, the method utilized was to give a brief explanation of the methodology's foundation, with the help of Figure 1, as it is outlined in the transcript file, so the rationale behind the decomposition of the problem was clear to the participants. Then, an explanation of the basis for the pairwise comparison procedure and the application of the fundamental scale of Table 4 was discussed, in order to go directly to the example and provide the steps to calculate the relative weights of the factors in the SWOT matrix. Once the calculations were explained by using the spreadsheet, most participants were able to build their own matrices without any further consultations, on both undergraduate and postgraduate groups.

\section{CONCLUSION}

In this paper, we have designed a teaching guide to provide students with the capacity to determine significant strategic factors in the 
planning process by combining SWOT with AHP techniques. It is possible to develop a quantitative management approach to support critical decisions, by using calculated priorities of SWOT factors.

On one side, students receive a knowledge that is not commonly offered in these courses, and that is very useful to build a high-quality foundation on real marketing applications. They understand that a means to reduce bias and subjectivity on the decision-making process is valuable for their professional background. Nevertheless, participants can also be advised that the AHP tool could be applied to a variety of situations where multi-criteria decision making is required. Teachers can provide references and examples of applications for other business environments, such as human resources, operations, among others.

Finally, this strategy supports the fact that marketing is not based primarily on conceptual contents, but far from it, the discipline involves putting together and analyzing data, models and simulations to get a better understanding of the marketplace and be able to design effective marketing plans.

\section{REFERENCES}

Coman, A. \& Ronen, B. (2009). Focused SWOT: diagnosing critical strengths and weaknesses. International Journal of ProductionResearch,47(20),5677-5689. doi: 10.1080/00207540802146130

Coyle, G. (2004). The analytic hierarchy process (AHP). Practical strategy: Structured tools and techniques, 1-11.

D’Alessio, I. F. (2008). El proceso estratégico: Un enfoque de gerencia. Lima, Perú: Pearson, Prentice Hall.

David, F. R. (2014). Strategic management: a competitive advantage approach, concepts \& cases $\left(15^{\text {th }}\right.$ Ed.). New Jersey: Prentice Hall.

Ferrell, O. C. \& Hartline, M. (2011). Marketing strategy $\left(5^{\text {th }}\right.$ Ed.). Ohio: Cengage Learning.

Friend, G. \& Zehle, S. (2004). Guide to business planning. London: Profile Books.

Görener, A., Toker, K. \& Uluçay, K. (2012). Application of combined SWOT and AHP: a case study for a Manufacturing Firm. Procedia-Social and Behavioral Sciences, 58, 1525-1534. doi:10.1016/j.sbspro.2012.09.1139

Hill, C., Jones, G. \& Schilling, M. (2014). Strategic management: theory: an integrated approach. Connecticut: Cengage Learning.

Hill, T. \& Westbrook, R. (1997). SWOT analysis: it's time for a product recall. Long range planning, 30(1), 46-52. doi:10.1016/ S0024-6301(96)00095-7

Jurevicius, 0. (2013). SWOT analysis. Do it properly! Retrieved from http://www. strategicmanagementinsight.com/ tools/swot-analysis-how-to-do-it. html

Kotler, P. \& Keller, K. L. (2015). Marketing management $\left(15^{\text {th }}\right.$ Ed.). New Jersey: Prentice Hall.

McDonald, M. (2011). Marketing plans: how to prepare them, how to use them $\left(7^{\text {th }}\right.$ Ed.). United Kingdom: Wiley.

Panagiotou, G. (2003). Bringing SWOT into focus. Business strategy review, 14(2), 8-10. doi:10.1111/1467-8616.00253

Rao, P. S. (2010). Strategic management. Mumbai: Himalaya Publishing House.

Rothaermel, F. T. (2012). Strategic Management: Concepts and Cases. New York: McGraw-Hill/Irwin.

Saaty, T. L. (1980). The Analytic Hierarchy Process. New York: McGraw-Hill. 
Sainz de Vicuña, J. M. (2010). El plan de marketing en la práctica (18 ${ }^{\text {th }}$ Ed.). Madrid: Esic Editorial.

Vass, K. (2005). A solid marketing plan begins with SWOT. Textile World, 155 (4), 18. 


\section{Appendix A \\ Suggested Class Transcript}

\section{Background}

This class has been developed partly because the impression received from other students was that the planning process information analysis stage is an area where most people feel that they have room for improvement. It is very likely that this tool has been reviewed or used before, in academic settings as well as at work, so the basic concept and mechanisms of the SWOT is well known. However, not only the fundamental theory will be reviewed, but also some enhancements to make the tool more convincing and useful.

\section{Definition and objectives}

According to David (2014), SWOT is an important adjustment tool that helps managers to develop four types of strategies: strengths and opportunities, weaknesses and opportunities, strengths and threats, and weaknesses and threats. Rothaermel (2012) wrote that it is a framework that allows managers to synthesize insights from an internal analysis of the company's strengths and weaknesses with those from an analysis of external opportunities and threats.

SWOT is an acronym that stands for:

Strengths: factors that give an edge for the company over its competitors

Weaknesses: factors that can be harmful if used against the firm by its competitors

Opportunities: favorable situations that can bring a competitive advantage

Threats: unfavorable situations that can negatively affect the business

Strengths and weaknesses are internal to the firm and can be directly managed by it, while the opportunities and threats are external and the firm can only foresee and react to them (Jurevicius, 2013). These four factors are called critical success factors, or CSFs.

SWOT is presented in a form of a matrix as shown in Slide 5, so general courses of action can be entered in the correspondent quadrant, as a result of opposing the internal CSF with the external one. To design the actions, a strength is used to take advantage of opportunities, and to avoid threats. In the same way, weaknesses must be overcome to be able to seize opportunities, and to avoid or diminish the impact of threats.

Benefits: Simple to do and practical to use, clear to understand, focuses on the key internal and external factors affecting the company, helps to identify future goals, and initiates further analysis (Jurevicius, 2013).

Limitations: No straightforward methodology is provided to identify and prioritize CSFs; most SWOT analyses focus on an excessive number of CSFs rather than on the main ones, which makes it difficult to utilize the findings to design actions; there is no indication of causality among the strengths and weaknesses, nor are they ranked into any hierarchy; and the SWOT analysis is typically a one-time event lacking procedures for acting upon and tracking the changes in CSFs over the longer term (Coman \& Ronen, 2009).

In order to overcome the subjective nature of the identification of CSFs, researchers have developed methods to provide a systematic framework aimed to improve results, as shown in the presentation slides (complementary PowerPoint file). 


\section{Identification of CSFs}

Strengths and weaknesses are the CSFs of the firm's internal environment. When looking for strengths, the question what does one do better than the competitors do? Must be asked. Alternatively, what do one have more valuable than the competitors have? In case of the weaknesses, the question to ask is what could one improve to defeat or at least catch up with competitors? Opportunities and threats are the external uncontrollable factors that usually appear or arise due to the changes in the macro environment, industry or competitors' actions (Jurevicius, 2013).

Another useful advice when identifying CSFs is to list three up to seven factors, to prevent creating too short or endless lists. CSFs must be facts, not opinions, so opinions should be kept unbiased. In Slide 8 you can find some links to additional tips on this matter.

One way to make sure that every relevant factor has been included is to have an itemized set of headers ready with categories of facts, so findings and observations can be entered at the upper segment of the matrices of Slide 9. Subsequent entries should then be made on the lower (SWOT) segment of the matrices according to the understanding of what is a company strength or weakness or what makes an opportunity or a threat. These variables should receive careful consideration and reflection based on their importance (Panagiotou, 2003).

\section{Prioritization with AHP}

The companies' resources are limited so it is not likely that someone can pay attention to all existent CSFs. Therefore, prioritization is necessary. As probably noted, this is not provided by the basic methodology, nor by the advices and methods mentioned before.
Saaty (1980) developed a method for decision making in complex multi-criteria scenarios, utilizing some empirical findings on human psychology and matrix algebra theorems. In the first place, the decision-making scenario is decomposed in hierarchy levels. For the SWOT analysis matrix, this operation can be modeled as shown in Slide 10, where the first level is the goal or objective to be achieved, the groups of CSFs form the second level, and the individual CSFs, the third level.

The second step of the process consists in determining the priorities of the CSFs, utilizing pairwise comparisons and assigning values to these by means of a scale - the fundamental scale-shown in Slide 11. The human mind tends to work best with a few elements at a time, despite its amazing capacities. This is why the comparison of the relative importance of factors is made taking two isolated CSFs at a time, instead of assessing the entire multicriteria set. For instance, if we compare the Strengths group with the Weaknesses group of factors, and we decide that the Strengths are slightly more important than the Weaknesses, we will assign a value of 3 to that pair comparison, according to the fundamental scale. Going further with this procedure with each CSFs group, we build the comparison matrix shown in Slide 12, where the elements below the diagonal are the reciprocal values of the comparison assigned values above the diagonal. The diagonal contains entries of 1 , as expected.

Then, to calculate the relative degree of importance of the SWOT groups, we utilize the formula in slide 13 , where the importance is given by the average of the ratio of every comparison in the row to the sum of comparisons from its corresponding column.

We repeat this procedure further down with the third level, the individual CSFs, building 
four comparison matrices, and calculating the relative degrees of importance of each factor. Finally, to find the overall relative importance of all of the CSFs in the SWOT matrix, we multiply the degrees of importance of the second level by the degrees of the third level.

The quality of the output of the AHP depends on the consistency of the pairwise comparison judgments, so the final stage is to calculate a Consistency Ratio (CR) to measure how consistent the judgements have been, relative to large samples of purely random judgments. If the CR is much in excess of 0.1 , the judgments are not reliable because they are too close for comfort to randomness and the exercise must be repeated (Coyle, 2004).

\section{Example}

To illustrate this procedure, an example of SWOT analysis of a new product is presented under permission. This case is mostly based on a project designed in 2014 by Clemencia Saldaña, Raúl Pinto, Jimena Reátegui, Marcos Salvador, and Gabriela Sevilla, students of a Marketing Plan course. An important and wellknown dairy products company plans to relaunch one of its instant coffee brands, which has little market share. The SWOT matrix is shown in Slide 14.

First, the pairwise comparison matrix of the SWOT groups is built; the results are shown in Slide 15. For instance, if the Strengths are considered slightly more important than the Weaknesses, then $1 / 3$ is entered in the SW cell, above the diagonal. The Excel formula calculates the reciprocal entry below the diagonal. Proceed in the same way for every pair above the diagonal, and the corresponding reciprocals will be calculated.

Slide 16 shows the next step, the calculation of a normalized matrix, where the relative weights of each CSFs group in the last column are obtained. As per this example, Opportunities is the group with the most importance or highest impact on the objective of the analysis.

Next, the pairwise comparison matrices for the CSFs of the third level will be created, in the same way as for the previous level. Slide 17 shows the results (normalization matrices not shown). The complementary spreadsheet file contains the complete calculations. The results indicate that opportunities 2, 3 and 4 are the most important CSFs to consider for the relaunching of this product.

For each comparison matrix, a consistency check will be performed, as detailed in Slide 18, and the corresponding section of the Excel file. The consistency ratio for all matrices is below 0.1 , which indicates that the judgments have been consistent relative to large samples of purely random judgments.

\section{(End of transcript)}

(c) The authors. This article is being published by the Educational Quality Department's Research Area Revista Digital de Investigación en Docencia Universitaria, Universidad Peruana de Ciencias Aplicadas (UPC). This is an open-access article, distributed under the terms of the Attribution-ShareAlike 4.0 International Creative Commons License (http://creativecommons.org/licenses/by-sa/4.0/), which allows the non-commercial use, distribution and reproduction in any media, provided the original work is properly cited. 